\title{
Improving combine harvester productivity as the main factor of increasing the economic efficiency of grain-harvesting process
}

\author{
${\text { Evgenia } \text { Muratova }^{1 *} \text {, Maria Glyzina }}^{1}$, Denis Muratov $^{2}$, and Elena Kravchenko ${ }^{3}$ \\ 1 Don State Technical University, 1, Gagarin Sq., 344003, Rostov-on-Don, Russia \\ 2 Intervesp, 5, Eremenko, 344041, Rostov-on-Don, Russia \\ 3 Rostov State University of Economics, 69, Bolshaya Sadovaya, 344002, Rostov-on-Don, Russia
}

\begin{abstract}
The research of the topical issue related to the improvement of air-sieve cleaning separation of the modern high-producing combine harvester is presented in the article. The calculation of economic efficiency of equipping combines with the suggested pneumatic and inertia separator is conducted in the paper. Research presented indicates the estimated efficient functioning of the cleaning design for small grain heap which helps to reduce grain losses and leads to the increase of combine harvester productivity.
\end{abstract}

\section{Introduction}

Grain production is historically considered to be an important sector of agricultural industry. At the same time, harvesting can be seen as the essential stage in the technological chain of grain production because its duration directly affects the harvested crop quality. The wide variety of crops and unpredictable weather influencing the harvesting time define the need for a manufacturer to develop high-producing and reliable combine harvesters. One of the possible ways of combine harvester performance improvement can be the increase of its productivity, which can be achieved by increasing the combine engine power, its speed, header width, hopper volume, the area of cleaning system sieves.

Today, not only domestic manufacturers, but also foreign combine harvester producers such as Claas, Challenger, John Deere, etc. have access to the Russian market. The domestic combine harvester plant PAO "Rostselmash" is a worthy competitor for foreign manufacturers of combines. This plant produces quality products both for domestic and foreign markets [4].

The core trends of the development of grain harvesting machinery in today's world include the significant increase in productivity and energy intensity of combine harvesters. In this regard, separating units of combines (straw rack and cleaning system) currently represent the elements that limit productivity growth, since the grain losses by straw rack and cleaning system increase sharply at certain values of capacity. Therefore, foreign enterprises are attempting to improve the quality of separation together with the change of the size of separation units. Some enterprises try to solve the problem of grain separation

\footnotetext{
* Corresponding author: geniahab@mail.ru
} 
improvement in the sieve pan by using the separator fan of the original design or by additional cleaning installation.

The review conducted shows that the main directions for combine harvester improvement include increasing the cleaning capacity by intensifying separation process, reducing grain losses, and improving the quality of cleaning on slopes. However, the limiting factor for the use of these designs is the complexity of their manufacturing.

The basis for the development of engineering solutions for improvement of process design of the combine harvester is determined by the enhancement of threshing and separating device, which is a very important field of the work of design engineers. That is why the emphasis must be put on projects needed to improve the cleaning system as one of the most important functions of the combine harvester.

It is necessary to adapt the air-sieve cleaning system to the increased feed of grain heaps in order to improve the quality of combine harvester cleaning system. The intensification of grain separation process is possible due to new engineering solutions that provide optimum kinematic and dynamic parameters of movement of transition grate, chaffer sieve and shoe sieve, and contribute to the rapid redistribution of grain heap particles to improve the air flow separation.

The use of combine harvesters has significantly reduced the share of manual labor in the agricultural sector and made it possible to harvest grain crops in a short time. However, another problem occurred related to the need of reducing grain losses by the combine separator. The grain losses by the combine separator lead to the decrease of gross charges of grain.

The reasons for grain losses during harvesting include the wrong choice of harvesting date or harvesting method, as well as overuse or misuse of grain harvesting equipment. It is generally acknowledged that grain losses largely depend on the operation of the combine air-sieve cleaning system. Combine harvester sieves perform grain separation. The threshed grain from the rotor goes to the sieves. Grain has a greater specific weight comparing to straw and chaff, that is why it freely passes down the sieve, and the rest of the grain mass is taken out of the combine by the air flow. The sieves of any combine harvester function according to this principle.

In the chaffer lipped screen cleaning system of modern combine harvesters, the separation process of the grain heap is activated by the grid, which is a continuation of the transition grate and is located above the chaffer lipped screen. However, such a preliminary separation of grain heap is not always efficient. In the combine harvester threshing drum, the degree of straw chopping increases especially at low humidity (with dried straw fraction) and, consequently, the yield of additional straw fractions for cleaning is increased too. The small fraction is generally predominant among them.

In the process of moving along the transition grate, grain particles do not fall on the grid after reaching the edge of the grate due to their small size but enter the chaffer lipped screen right after leaving the transition grate. Movement of the straw part of the heap from the transition grate to the grid and its further movement over the entire surface of the grid is a randomized process, since it occurs not only when the grid vibrates, but also in the area of air flow created by the fan. The odds of straw fraction getting on the grid depend not only on its size, but also on the location of particles in the process of moving along the transition grate surface. If the particles are located transversely to the moving direction and their length is greater than the grid spacing, then the probability of getting on the grid surface and then moving along it increases. Straw particles located at an angle to the grid pins will be able to move along it if they come into contact with adjacent pins. The particles located along the moving direction do not fall on the grid and together with their fine fraction get onto the chaffer sieve surface contributing to the significant increase in the heap layer thickness. The removal of straw particles by the air flow of the fan from the surface of the 
chaffer sieve decreases, which leads to separation degradation in the heap layer itself (the grain passage from the upper layers to the lower ones, i.e., to the sieve surface).

In addition, the air swirl is observed, the flows rush anywhere, and air speed at the end of the sieve drops more than four times, which should not be happening. Thus, the mass is retained, which consequently leads to overloading of sieves with the grain heap. This negatively affects the delivery of the grain mass to the thresher. As a result, the increase in grain losses after sieve cleaning is observed, which already brings an unsatisfactory effect even without this in contrast to modern screen-air cleaning with lipped screens in the form of a row of rakes that is provided in modern combines. The technical solution for combine cleaning separation improvement based on the use of appropriate design of air-sieve cleaning is suggested and economically grounded in this article.

\section{Materials and methods}

The economic justification of the project aimed at enhancing the cleaning system of the combine harvester is carried out on the example of the Vector 410 combine and includes determining the economic efficiency of the project both for the manufacturer of these combine harvesters and for their consumer. The calculation is made using the methods of determining the break-even of the project, discounting and calculating the profitability index.

To determine the operating costs savings for the consumer the items of operating costs are calculated in the paper, which will change as a result of the implementation of the suggested technical solution. The effect for the consumer $\left(E_{c}\right)$ can be represented in the form of operating costs decrease in comparison with the basic case and determined by the formula:

$$
E_{c}=I_{B A Z}-I_{P R O J E C T},
$$

where $I_{B A Z}$ is the annual operating costs in case of existing combine usage, rubles;

$I_{P R O J E C T}$ is the annual operating costs in case of usage of improved combine, rubles.

Operating costs usually include, among others, the wage of personnel $\left(Z_{p(\text { komb })}\right)$ and energy costs $(E)$ (fuel, electricity, etc.). In this calculation, the determination of the combine operating costs $(I)$ is carried out only for those types of costs because they are different for the compared cases:

$$
I=Z_{p(k o m b)}+E
$$

The annual wages of combine $\operatorname{driver}\left(Z_{p(k o m b)}\right)$ are defined as:

$$
Z_{p(k o m b)}=S_{R} \times T \times D,
$$

where $S_{R}$ is the estimated rate of pay, rubles;

$T$ is the number of working hours per day, hours;

$D$ is the number of working days per year, days.

Fuel costs $(E)$ can be determined using a formula:

$$
E=N \times q \times k_{\mathrm{M}} \times C_{g} \times F,
$$


where $N$ is the combine engine power rating, hp;

$q$ is the specific fuel consumption per $1 \mathrm{hp}, \mathrm{kg} / \mathrm{h}$;

$k_{\mathrm{M}}$ is the engine capacity utilization factor;

$C_{g}$ is the price of $1 \mathrm{~kg}$ of the fuel, rubles;

$F$ is the annual combine working time fund, hours.

The discounted profit $\left(P_{t}^{D}\right)$ for the consumer is defined as follows:

$$
P_{t}^{D}=E_{c}^{t} \times K_{D}
$$

where $E_{c}^{t}$ is the annual operating costs savings due to the use of improved combine, rubles;

$K_{D}$ is the discount coefficient defined using the formula:

$$
K_{d}=\frac{1}{(1+E)^{t}}
$$

where $E$ is the discount rate equal to the acceptable by the investor rate of return on capital;

$t$ is the number of years of project implementation $(t=0,1,2, \ldots, n)$.

The profitability index $(I D)$ shows the exceedance of the income earned over the invested funds and is determined by the formula:

$$
I D=\frac{\sum_{t=0}^{n} P_{t}^{D}}{K},
$$

where $K$ is additional investments, rubles;

$n$ is the period of project implementation, years.

\section{Results}

The relevant solution to the problem of increasing the efficiency of air-sieve cleaning separation can include the process of enriching a heap with grain. In this case the heap improves the performance of grain sifting through this sieve upon entering the chaffer sieve of the air-sieve cleaning. Consequently, the development of this direction can lead to designing the air-sieve cleaning, which can increase the level of grain cleaning quality, help to decrease grain losses, and provide purity of the grain in the bunker.

The findings of the research conducted led to the conclusion about the possibility of pneumatic and inertia separator use in the design of small grain heap cleaning of the highproducing combine harvester, which in turn serves as a starting point for economic benefit achievement $[1,2]$. The engineering study carried out earlier made it possible to conclude that the existing features of the system operation include the acceleration of the grain heap feed by the blade rotor, while the grain heap is fed only to the surface of the chaffer sieve made of separating elements, where the air is blown actively. Installation of an eight-bladed rotor for experimental cleaning system over the chaffer sieve taking into account the required size restrictions and minimal renovation of the existing air-sieve cleaning with the blades positioned radially is shown in Figure 1. 


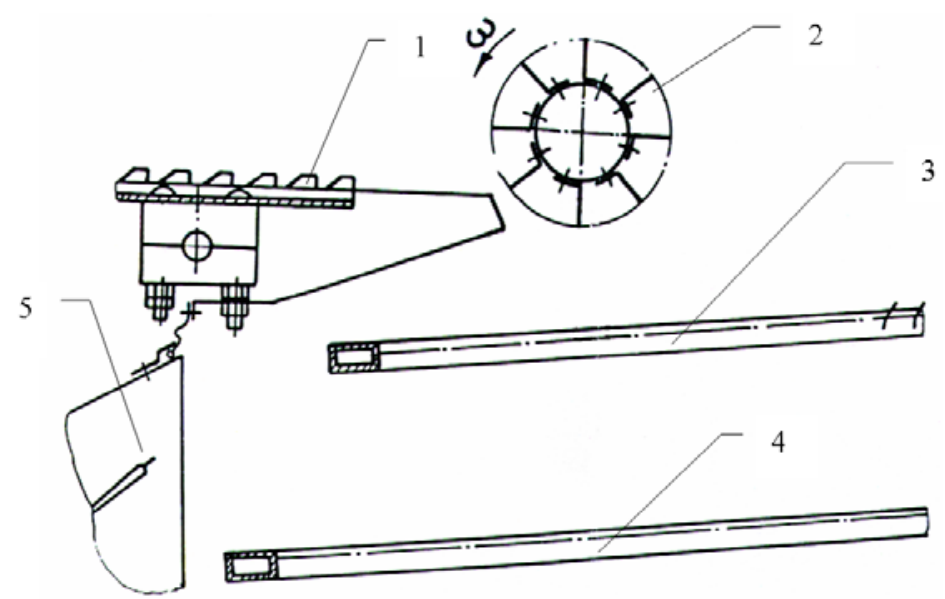

Fig. 1. Pneumatic and inertia separator in the combine cleaning: 1 - shaking board; 2 - bladed rotor; 3 - chaffer sieve; 4 - shoe sieve; 5 - centrifugal fan

Let us consider the potential economic efficiency of the Vector 410 combine cleaning improvement project aimed to reduce grain losses and increase the productivity of grainharvesting performance. The main indicators required for the calculation are presented in Table 1.

Table 1. Indicators needed for calculations.

\begin{tabular}{|l|c|c|c|}
\hline \multicolumn{1}{|c|}{ Indicator } & $\begin{array}{c}\text { Unit of } \\
\text { measurement }\end{array}$ & $\begin{array}{c}\text { Basic case } \\
\text { (without project } \\
\text { implementation) }\end{array}$ & $\begin{array}{c}\text { Projected case } \\
\text { (including } \\
\text { project } \\
\text { implementation) }\end{array}$ \\
\hline Combine output & $\mathrm{t} / \mathrm{h}$ & 12 & 12.8 \\
\hline Engine power rating & $\begin{array}{c}\mathrm{kW} \\
\mathrm{hp})\end{array}$ & $\begin{array}{c}210 \\
(154)\end{array}$ & 0.96 \\
\hline Engine capacity utilization factor & - & 10 & 10 \\
\hline Lifetime of the machine & years & 88 & 84 \\
\hline Number of working days per year & days & 7 & 7 \\
\hline Number of working hours per day & hours & 1 & 1 \\
\hline Number of workers & people & 165 & 165 \\
\hline Average hourly pay rate & rubles & 60 & 60 \\
\hline Bonus & $\%$ & & \\
\hline
\end{tabular}

The cost and price values of the Vector 410 combine harvester before and after the improvement are shown in Table 2.

As indicated in Table 2, the cost of the combine harvester under consideration increased by $1 \%$, which led to the increase of the machine sale price by 56427 rubles. The costs of production and sale of combines for three years are shown in Table 3. 
Table 2. Cost and price values of the Vector 410 combine harvester, thousand rubles.

\begin{tabular}{|l|c|c|}
\hline \multicolumn{1}{|c|}{ Indicator } & Basic case & Projected case \\
\hline Production cost & 4478.679 & 4522.859 \\
\hline Full cost & 4613.04 & 4658.54 \\
\hline Sale price & 5720.169 & 5776.596 \\
\hline Price including VAT & 6864.203 & 6931.915 \\
\hline
\end{tabular}

Table 3. Estimated costs of production and sale of the combine with improved cleaning system.

\begin{tabular}{|l|c|c|c|}
\hline \multicolumn{1}{|c|}{ Cost items } & $\mathbf{2 0 2 2}$ & $\mathbf{2 0 2 3}$ & $\mathbf{2 0 2 4}$ \\
\hline Sales volume, pcs (for reference) & 150 & 218 & 244 \\
\hline Material costs, thousand rubles & 491469 & 714268 & 799456 \\
\hline Basic wages, thousand rubles & 28500 & 41420 & 46360 \\
\hline Additional wages, thousand rubles & 5700 & 8284 & 9272 \\
\hline $\begin{array}{l}\text { Insurance charge (30\% of the wages), } \\
\text { thousand rubles }\end{array}$ & 10260 & 14911 & 16689 \\
\hline Manufacturing expenses, thousand rubles & 85500 & 124260 & 139080 \\
\hline $\begin{array}{l}\text { General business expenses, thousand } \\
\text { rubles }\end{array}$ & 57000 & 82840 & 92720 \\
\hline $\begin{array}{l}\text { Selling and marketing costs, thousand } \\
\text { rubles }\end{array}$ & 20353 & 29579 & 33107 \\
\hline Full costs, thousand rubles & 698782 & 1015781 & 1136929 \\
\hline
\end{tabular}

The results of calculating break-even condition for the first year of production of improved combines are provided in Table 4.

The suggested project is considered financially sustainable since the financial safety margin factor exceeds $30 \%$. In this case the project is considered to be financially stable for the improved combine manufacturer because the financial safety margin factor is $49 \%$ in accordance with the data in Table 4.

Table 5 presents the results of calculating the changing items of operating costs for the company - consumer of the improved combine harvester. 
Table 4. Calculation of break-even condition and financial safety margin of the project.

\begin{tabular}{|c|c|c|}
\hline Indicator & $\begin{array}{c}\text { Unit of } \\
\text { measurement }\end{array}$ & $\begin{array}{c}\text { The year of the } \\
\text { project } \\
2022\end{array}$ \\
\hline Sales volume & pcs & 150 \\
\hline Income & $\begin{array}{c}\text { thousand } \\
\text { rubles }\end{array}$ & 866489 \\
\hline Total cost of annual output of machines & $\begin{array}{c}\text { thousand } \\
\text { rubles }\end{array}$ & 698782 \\
\hline Before-tax profit & $\begin{array}{c}\text { thousand } \\
\text { rubles }\end{array}$ & 167708 \\
\hline Tax on profits & $\begin{array}{c}\text { thousand } \\
\text { rubles }\end{array}$ & 33542 \\
\hline Net profit & $\begin{array}{c}\text { thousand } \\
\text { rubles }\end{array}$ & 134166 \\
\hline Fixed costs & $\begin{array}{c}\text { thousand } \\
\text { rubles }\end{array}$ & 174695.43 \\
\hline Variable costs & $\begin{array}{c}\text { thousand } \\
\text { rubles }\end{array}$ & 524086.29 \\
\hline Share of variable costs in sales volume & $\%$ & 60 \\
\hline \multirow[t]{2}{*}{ Break-even volume } & $\begin{array}{c}\text { thousand } \\
\text { rubles }\end{array}$ & 442086.39 \\
\hline & pcs & 76 \\
\hline Financial safety margin & $\begin{array}{c}\text { thousand } \\
\text { rubles }\end{array}$ & 424402.94 \\
\hline Financial safety margin factor & $\%$ & 49 \\
\hline
\end{tabular}

Table 5. Summary table of changing items of operating costs, rubles

\begin{tabular}{|l|c|c|c|}
\hline \multicolumn{1}{|c|}{ Operating cost items } & Basic case & Projected case & Savings \\
\hline Wages of combine driver & 162624 & 155232 & 7392 \\
\hline Insurance charge & 48787 & 46569 & 2218 \\
\hline Fuel costs & 1046138 & 998587 & 47551 \\
\hline Total & 1257551 & 1200389 & 57161 \\
\hline
\end{tabular}

The annual savings on operating costs of the basic and improved combine are defined as the difference between the operating costs of the basic and upgraded equipment. Thus, the savings on operating costs of the improved combine harvester in comparison with the basic one is 57161 rubles per year. Consequently, despite the excess of the sale price of the improved combine by 56427 rubles compared to the basic one, it is more profitable for the consumer to purchase the improved machine, since this decision will lead to getting the savings on operating costs during the period of combine harvester use.

The discounted profit for 10 years (lifetime of the combine) at a discount rate of $15 \%$ is calculated in Table 6 . 
Table 6. Calculation of the discounted profit for the consumer.

\begin{tabular}{|c|c|c|c|}
\hline Period & $\begin{array}{c}\text { Annual savings, } \\
\text { rubles }\end{array}$ & Discount coefficient & $\begin{array}{c}\text { Discounted profit, } \\
\text { rubles }\end{array}$ \\
\hline 1 & 57161 & 0.8696 & 49706 \\
\hline 2 & 57161 & 0.7561 & 43222 \\
\hline 3 & 57161 & 0.6575 & 37585 \\
\hline 4 & 57161 & 0.5718 & 32682 \\
\hline 5 & 57161 & 0.4972 & 28419 \\
\hline 6 & 57161 & 0.4323 & 24712 \\
\hline 7 & 57161 & 0.3759 & 21489 \\
\hline 8 & 57161 & 0.3269 & 18686 \\
\hline 9 & 57161 & 0.2843 & 16249 \\
\hline 10 & 57161 & 0.2472 & 14129 \\
\hline Total & - & - & 286880 \\
\hline
\end{tabular}

Let us use the calculations shown in Table 6 to determine the profitability index. The calculation results are summarized in Table 7.

Table 7. Calculation of the economic effect for the consumer, rubles.

\begin{tabular}{|l|c|}
\hline \multicolumn{1}{|c|}{ Indicator } & Value for a 10-year period \\
\hline Discounted profit & 286880 \\
\hline Additional investments & 74483 \\
\hline Cumulative net present value & 212396.57 \\
\hline Profitability index & 3.85 \\
\hline
\end{tabular}

Thus, the economic efficiency calculation of the suggested technical solution shows that the consumer of the combine harvester can get additional savings on operating costs in case of purchasing the improved combine instead of the basic one, since the improvement of the Vector 410 harvester will reduce grain losses and increase its productivity by $6.7 \%$. The profitability index is 3.85 , which is more than 1 , therefore, the suggested project can be considered cost-effective.

\section{Conclusions}

The economic efficiency of the combine improvement project is defined in the work. The project includes equipping the combine with the pneumatic and inertia separator of small grain heaps to reduce grain losses and increase the productivity of the combine harvester. The calculation conducted using the example of the Vector 410 combine showed potential economic effect of the project for both the manufacturer and consumer of combines. The use of the improved combine harvester will provide savings on operating costs for the consumer in comparison with the basic version of the machine in the annual amount of 57161 rubles due to the increased productivity of the combine. The financial safety margin factor of the project for the combine manufacturer exceeds $30 \%$, which indicates the sufficient financial stability of the project.

Thus, one of the possible ways to increase the efficiency of cleaning separation can be the grain enrichment of the heap feeding to chaffer sieve and intensification of grain sifting through this sieve. This solution makes it possible to develop the air-sieve cleaning with the pneumatic and inertia separator for high-producing combine harvester which provides a 
$30 \%$ decrease of grain losses during the cleaning process in comparison with the seriesproduced one. Cleaning improvement will provide agricultural production with the equipment with higher agrotechnical capabilities and lower material costs. Therefore, the increase of combine harvester productivity can be considered as the main factor of increasing the economic efficiency of the grain-harvesting process.

\section{References}

1. E. Muratova, D. Muratov, E. Makarenko, S. Shepelev, O. Korobeynikova, V. Chegge and Y. Kabanova, E3S Web Conf, 175, 01009 (2020) doi.org/10.1051/e3sconf/202017501009.

2. E. Muratova, D. Muratov, E. Kravchenko, A. Sukhoveeva, O. Andreeva, E3S Web Conf., 210, 05010 (2020) doi.org/10.1051/e3sconf/202021005010

3. N.S. Plaskova, N.A. Prodanova, A.S. Samusenko, E.A. Erzinkyan, K.A. Barmuta, R.A. Shichiyakh, International Journal of Engineering and Advanced Technology, 29132916 (2019) DOI: 10.35940/ijeat.A1213.109119.

4. A. Butovchenko, A. Doroshenko, A. Kol'Cov, V. Serdyuk, E3S Web Conf., 135, 01081 (2019) doi.org/10.1051/e3sconf/201913501081

5. V.V. Mazur, K.A. Barmuta, S.S. Demin, E.A. Tikhomirov, M.A. Bykovskiy, International Journal of Economics and Financial Issues, 6(1S), 270-274 (2016)

6. K.A. Barmuta, E.M. Akhmetshin, I.Y. Andryushchenko, G.V. Meshkova, A.O. Zekiy, Entrepreneurship and Sustainability Issues, 8(1), 945-959 (2020) doi.org/10.9770/jesi.2020.8.1(63)

7. L.V. Borodacheva, A.F. Goloborodov, A.I. Guseva, A.A. Drozdova, M.P. Glyzina, International Journal of Economics and Financial Issues, 6 (1S), 306-311 (2016)

8. F.A. Kipriyanov, P.A. Savinykh, Foundation for Enviromental Protection and Research, J Biosci, 13(2), 1651-1658 (2019)

9. K.A. Barmuta, et. al. Contemporary aspects of innovation economy and management development (Rostov-on-Don: DSTU publishing center), 159, (2020)

10. A. Izmailov, M. Moskovskiy, D. Podlesniy, MATEC Web of Conferences, 224, 05010 (2018) doi.org/10.1051/matecconf/201822405010

11. I. Khozyaev, V. Ladyanov, L. Enalyeva, M. Balinskaya, V. Zharov, E3S Web Conf., 135, 01103 (2019) doi.org/10.1051/e3sconf/201913501103.

12. A. Solonenko, L. Medvedeva and Y. Mostovaya, E3SWeb Conf., 175, 13010 (2020) doi.org/10.1051/e3sconf/202017513010

13. Y. Lachuga, A Soloviev, A Matrosov, I Panfilov, V Pakhomov, D Rudoy, Conf. Series: Earth and Environmental Science, 403, 012055 (2019) doi:10.1088/17551315/403/1/012055

14. K. Timoleanov, D. Savenkov, L., Gorgadze MATEC Web of Conferences, 224, 05020 (2018) DOI: 10.1051/matecconf/201822405020

15. Y. Tsarev, E. Adamcikova, M. Najie, MATEC Web of Conferences, 224, 05019 (2018) DOI:10.1051/matecconf/201822405019/ 